\title{
Analysis and comparison of nutrient contents in different animal manures from Beijing suburbs
}

\author{
Zengling Yang, Lujia Han* \\ College of Engineering, China Agricultural University, Beijing, China; ${ }^{*}$ Corresponding Author: hanlj@cau.edu.cn
}

Received 10 October 2013; revised 14 November 2013; accepted 26 November 2013

Copyright (C) 2013 Zengling Yang, Lujia Han. This is an open access article distributed under the Creative Commons Attribution License, which permits unrestricted use, distribution, and reproduction in any medium, provided the original work is properly cited.

\begin{abstract}
Manure samples were collected by floor scrapings in animal stables from Beijing suburbs. Total nitrogen (TN), total phosphorus (TP), and total potassium (TK) were analyzed by conventional wet chemical methods. All manures showed a high variability in nutrient contents. Nutrients contents in different animal manures were significantly different. TN and TK contents in layer manures were higher than swine and dairy manures $(p<0.001)$, and TP content in swine manures was higher than layer and dairy manures $(p<0.001)$. Different nutrients contents were also significantly different. For all three types of manures, the TN content was the highest $(p<0.001)$, and TP content was higher than TK content significantly in swine manures $(p<$ 0.001), while TK content was higher than TP content in layer manures $(p=0.01)$, and there was no significant difference between TK and TP contents in dairy manures $(p=0.208)$. Furthermore, the distribution characteristics of nutrient contents in different manures were studied.
\end{abstract}

Keywords: Animal Manures; Nutrient Content; Analysis; Comparison; Distribution

\section{INTRODUCTION}

Livestock manure, which contains high concentration of important nutrients (mainly nitrogen, phosphorus and potassium) for the plants, is one of the important biomass resources for the farmland. Moderate land application of livestock manure on farmland is a direct and effective way to recycle nutrient, to improve soil fertility and to protect environment. On the other hand, excessive discharge of livestock manure on farmland would pose a great threat to the ground/surface water environment and cause nutrient loss $[1,2]$. Nutrient contents in manures varied significantly because of the variability of feed, rearing technologies and feeding practice $[3,4]$. Analyzing the nutrient contents in livestock manure is important for the management and utilization of livestock manure resources. The subject attracted wide public interest and many studies were reported [2,5-16]. Nutrient content in livestock manure can be influenced by collection technology, storage methods or storage periods $[2,10]$. Reported studies on livestock manure nutrient content were mostly on pit manure [17,18], liquid lagoon [17-19], solid hoop [18,19] and slurry [17,19]. Floor scraping in animal stables is widely used for manure sample collection, which can significantly reduce water consumption and bulk materials of the manures collected.

China is one of the countries with large scale animal husbandry, where the intensive breeding or breeding in large scale becomes the main practice, especially in the suburbs beside the big cities. Large and medium-sized intensive breeding farms in Beijing suburbs rank the second nationwide [20] and reached more than $80 \%$ [21]. Swine, layer hen and dairy are the most common livestocks in Beijing suburbs. In this study, swine, layer hen and dairy manure samples were collected by floor scrapings in animal stables from intensive breeding farms located in Beijing suburbs. Total nitrogen (TN), total phosphorus (TP), and total potassium (TK) were analyzed and compared. The result will be helpful for estimating the amount of animal manure nutrient discharged to agricultural land and establishing the application standard based on the maximum nutrient load limit. Furthermore, the result can provide the data base to utilize the manures safely, rationally and efficiently so as to protect the environment and develop sustainable animal husbandry and agriculture.

\section{MATERIALS AND METHODS}

\subsection{Sample Collection and Preparation}

Three types of manure samples (swine, layer and dairy) were collected from a number of intensive breeding 
farms located in Yanqing, Huairou, Changping, Shunyi, Pinggu, Tongzhou and Daxing districts of Beijing suburbs (Figure 1). Samples were collected by floor scrapings in animal stables. A total of 301 samples were collected, including 108 swine manure samples, 91 layer manure samples and 102 dairy manure samples. No straw or straw dust was present in collected samples. Table 1 shows the general information of the collected samples.

Samples were mixed and dried in oven at $70^{\circ} \mathrm{C} \pm 5^{\circ} \mathrm{C}$. Hydrochloric acid solution of $5 \%(\mathrm{v} / \mathrm{v})$ was sprayed over each sample before drying in order to avoid volatilization of ammonia nitrogen. Samples were ground to pass 0.5 $\mathrm{mm}$ sieve using a cyclonic mill and stored in air-tight container for wet chemistry analysis.

\subsection{Wet Chemistry Analysis}

Moisture, total nitrogen (TN), total phosphorus (TP), and total potassium (TK) contents in each manure samples were analyzed with three replications using conventional wet chemical procedures as described in Table 2 $[22,23]$.

\subsection{Data Analysis}

Data obtained from the nutrient contents were analyzed using SPSS v16.0 (Statistical Package for the Social Science). Descriptive statistics were used to analyze the nutrient contents in each type of manures. Post hoc multiple comparisons were applied to analyze the difference in nutrient contents between different types of manures. Homogeneity of variance test was used before post hoc multiple comparisons. If the variances were equal ( $\mathrm{p}>0.05)$, S-N-K (Student-Newman-Keuls) test would be used for analysis. Otherwise (i.e. $\mathrm{p}<0.05$ ), the Tamhane's T2 test would be used. For post hoc multiple comparisons, the differences were significant if $\mathrm{p}<0.05$ [24].

The distribution characteristics of nutrient contents in each type of manures were examined using histogram plot. Furthermore, the one-sample Kolmogorov-Smirnov test, which belongs to nonparametric tests, was used to test whether the nutrient content variations of the three types of manures were normally distributed. A probability value of the $Z$ statistic above 0.05 implies that the variation was normally distributed [24].

\section{RESULTS AND DISCUSSIONS}

\subsection{Analysis and Comparison of Nutrient Contents in Different Manures}

Measured moisture contents of swine, layer and dairy manures varied between 630.9 - $820.0 \mathrm{~g} \cdot \mathrm{kg}^{-1}, 623.9$ $868.4 \mathrm{~g} \cdot \mathrm{kg}^{-1}$ and $550.6-867.2 \mathrm{~g} \cdot \mathrm{kg}^{-1}$ respectively. The mean values of moisture contents were $726.3 \mathrm{~g} \cdot \mathrm{kg}^{-1}$ for swine manure, $711.6 \mathrm{~g} \cdot \mathrm{kg}^{-1}$ for layer manure and 785.6 $\mathrm{g} \cdot \mathrm{kg}^{-1}$ for dairy manure. The moisture contents in the three types of manures, which were collected by floor scrapings in animal stables, were similar.

Table 3 lists the contents and variations of TN, TP and TK in swine, layer and dairy manures on dry matter basis.

From Table 3, the following can be observed:

1) The mean values of TN, TP and TK were 32.45 $\mathrm{g} \cdot \mathrm{kg}^{-1} \mathrm{DM}, 17.87 \mathrm{~g} \cdot \mathrm{kg}^{-1} \mathrm{DM}$ and $14.04 \mathrm{~g} \cdot \mathrm{kg}^{-1} \mathrm{DM}$ for swine manures; $54.74 \mathrm{~g} \cdot \mathrm{kg}^{-1} \mathrm{DM}, 14.64 \mathrm{~g} \cdot \mathrm{kg}^{-1} \mathrm{DM}$ and $17.94 \mathrm{~g} \cdot \mathrm{kg}^{-1} \mathrm{DM}$ for layer manures; $18.23 \mathrm{~g} \cdot \mathrm{kg}^{-1} \mathrm{DM}$, $5.50 \mathrm{~g} \cdot \mathrm{kg}^{-1} \mathrm{DM}$ and $6.12 \mathrm{~g} \cdot \mathrm{kg}^{-1} \mathrm{DM}$ for dairy manures. The total nutrient contents $(\mathrm{TN}+\mathrm{TP}+\mathrm{TK})$ in swine, layer and dairy manures were $64.36 \mathrm{~g} \cdot \mathrm{kg}^{-1} \mathrm{DM}, 88.05 \mathrm{~g} \cdot \mathrm{kg}^{-1}$

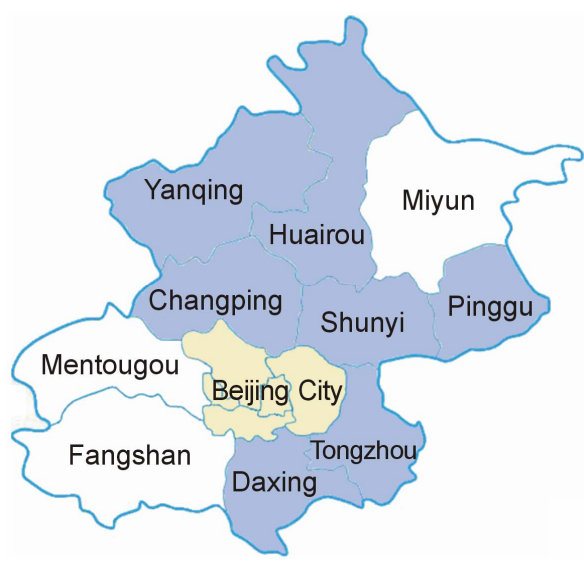

Figure 1. Districts livestock manure samples collected.

Table 1. Sample information.

\begin{tabular}{ccc}
\hline Type & Breeds & Growth period \\
\hline $\begin{array}{c}\text { Swine } \\
\text { manure }\end{array}$ & $\begin{array}{c}\text { Duroc, Landrace, Large White, Chinese Large Black } \\
\text { and White, Pietrain, Landrace } \times \text { Large White, Duroc } \times \\
\text { Landrace } \times \text { Large White }\end{array}$ & Growing-finishing \\
$\begin{array}{c}\text { Layer } \\
\text { manure }\end{array}$ & Hi-Line Brown, Hi-Line Grey, Roman laying hens & Brooding, growing, and laying \\
$\begin{array}{c}\text { Dairy } \\
\text { manure }\end{array}$ & Chinese Holstein Cows & Daxing, Changping, Tongzhou \\
Replacement heifers, Adult \\
lactating cows
\end{tabular}


Table 2. Laboratory analysis methods.

\begin{tabular}{ccc}
\hline Measured variable & Abbreviation & Laboratory method \\
\hline Moisture $\left(\mathrm{g} \cdot \mathrm{kg}^{-1}\right)$ & moisture & Oven-drying at $70^{\circ} \mathrm{C}$ \\
Total nitrogen $\left(\mathrm{g} \cdot \mathrm{kg}^{-1} \mathrm{DM}\right)$ & $\mathrm{TN}$ & Digestion in sulfuric acid followed by steam distillation \\
Total phosphorus $\left(\mathrm{g} \cdot \mathrm{kg}^{-1} \mathrm{DM}\right)$ & $\mathrm{TP}$ & Microwave digestion in nitric acid followed by spectrometric method \\
Total potassium $\left(\mathrm{g} \cdot \mathrm{kg}^{-1} \mathrm{DM}\right)$ & $\mathrm{TK}$ & Microwave digestion in nitric acid followed by atomic absorption \\
spectrophotometry
\end{tabular}

Table 3. Analysis and comparison of nutrient contents based on dry matter (DM).

\begin{tabular}{|c|c|c|c|c|}
\hline & & Swine & Layer & Dairy \\
\hline \multirow{4}{*}{$\begin{array}{c}\text { Mean } \pm \text { SD } \\
\left(\mathrm{g} \cdot \mathrm{kg}^{-1} \mathrm{DM}\right)\end{array}$} & $\mathrm{TN}$ & $32.45 \pm 4.88^{\mathrm{b}, \mathrm{A}}$ & $54.74 \pm 27.82^{\mathrm{a}, \mathrm{A}}$ & $18.23 \pm 4.05^{\mathrm{c}, \mathrm{A}}$ \\
\hline & $\mathrm{TP}$ & $17.87 \pm 4.00^{\mathrm{a}, \mathrm{B}}$ & $14.64 \pm 5.01^{\mathrm{b}, \mathrm{C}}$ & $5.50 \pm 1.68^{\mathrm{c}, \mathrm{B}}$ \\
\hline & $\mathrm{TK}$ & $14.04 \pm 4.23^{\mathrm{b}, \mathrm{C}}$ & $17.94 \pm 10.66^{\mathrm{a}, \mathrm{B}}$ & $6.12 \pm 3.05^{\mathrm{c}, \mathrm{B}}$ \\
\hline & $\mathrm{TN}+\mathrm{TP}+\mathrm{TK}$ & $64.36 \pm 8.02^{\mathrm{b}}$ & $88.05 \pm 38.42^{\mathrm{a}}$ & $29.90 \pm 6.06^{c}$ \\
\hline \multirow{4}{*}{$\begin{array}{c}\text { Range } \\
\left(\mathrm{g} \cdot \mathrm{kg}^{-1} \mathrm{DM}\right)\end{array}$} & $\mathrm{TN}$ & $19.37-45.89$ & $22.06-159.60$ & $8.32-26.20$ \\
\hline & $\mathrm{TP}$ & $10.64-34.91$ & $4.12-34.97$ & $2.46-9.03$ \\
\hline & $\mathrm{TK}$ & $2.04-22.04$ & $5.63-76.49$ & $2.21-18.35$ \\
\hline & $\mathrm{TN}+\mathrm{TP}+\mathrm{TK}$ & $37.39-84.33$ & $40.61-223.88$ & $14.95-47.81$ \\
\hline \multirow{4}{*}{$\begin{array}{l}\text { CV } \\
(\%)\end{array}$} & $\mathrm{TN}$ & 15 & 51 & 22 \\
\hline & $\mathrm{TP}$ & 22 & 34 & 31 \\
\hline & TK & 30 & 59 & 50 \\
\hline & $\mathrm{TN}+\mathrm{TP}+\mathrm{TK}$ & 13 & 44 & 20 \\
\hline
\end{tabular}

Note: the different letters (a,b,c for columns; A, B,C for rows) mean statistically different.

DM and $29.90 \mathrm{~g} \cdot \mathrm{kg}^{-1} \mathrm{DM}$ respectively. According to the method of Wang et al. [25], the amount of total discharged TN, TP and TK in all three types of manures could be estimated to be 46,222 t, 21,190 t and 18,998 t in Beijing area (number of slaughtered fattened pigs yearly is $3,140,400$; number of dairy cattle is 103,700 in year end; number of layer hen is 13,588,200 in year end in Beijing area [26]). There were 1,095,981 ha agricultural land of Beijing in 2008 [26]. The average TN, TP and TK load in Beijing can be estimated to be about 42 $\mathrm{kg} \cdot \mathrm{ha}^{-1}, 19 \mathrm{~kg} \cdot \mathrm{ha}^{-1}$ and $17 \mathrm{~kg} \cdot \mathrm{ha}^{-1}$.

2) The variations of $T N, T K$, and $T P$ contents were measured in each type of manures. The coefficient of variability $(\mathrm{CV})$ of the TN contents was $15 \%$ for swine manure, $51 \%$ for layer manure and $22 \%$ for dairy manure. The TN content in layer manure varied the most, with the maximum value about 7 times of the minimum value. The CV values of the TP contents in swine, layer and dairy manures were $22 \%, 34 \%$ and $31 \%$ respectively, suggesting similar levels of variations of TP in the three types of manures, and the variation of TP contents in swine manure was the lowest. The CV values of the TK contents in swine, layer and dairy manures were $30 \%$, $59 \%$, and $50 \%$. The variation of TK in layer and dairy manures was higher than in swine manure. The CV values of the total nutrient contents in swine, layer and dairy manures were $13 \%, 44 \%$, and $20 \%$ respectively. The variation of total nutrient was highest in layer and lowest in swine. The high variation of TN, TP and TK contents in different manures was possibly caused by different livestock species, feed, nutrient absorbing rate, rearing periods or rearing mode.

3) The difference of nutrient contents in different manures was tested by post hoc multiple comparisons test. Nutrient contents in different animal manures were significantly different according to the results of post hoc multiple comparisons test. TN content was the highest in layer manures and lowest in dairy manures $(\mathrm{p}<0.001)$. One main reason of the highest TN content in layer manure was non-separation of feces and urine. TP content was the highest in swine manures and lowest in dairy manures $(\mathrm{p}<0.001)$. The higher TP content in swine and layer manure could be due to that most of phytase in feed is less fully digested by the single-stomach animal. TK content was the highest in layer manures and lowest in dairy manures $(\mathrm{p}<0.001)$. Total nutrient content in layer manures was the highest $(p<0.001)$ followed by that in the swine $(p<0.001)$ and then in dairy manures. The mean value of total nutrient in dairy manures was only $46 \%$ of that in swine manures and $34 \%$ in layer manures. The probable reason for the difference could be the digestive and feed composition characteristics. Roughages 
are necessary for ruminant animals and the nutrient contents of roughages are lower than that of compound feed. Furthermore, due to rumen in ruminant digestive tract, the nutrients in dairy feed were more fully utilized.

Differences of nutrient content in the same animal manure were also tested by post hoc multiple comparisons test. The results indicate that all three types of manures had the highest TN contents $(\mathrm{p}<0.001)$. The lowest nutrient content in swine manure was TK $(\mathrm{p}<0.001)$ and the lowest nutrient content in layer manure was TP $(\mathrm{p}=0.01)$. The TP and TK contents in dairy manures were similar $(\mathrm{p}=0.208)$.

\subsection{Distribution Characteristics of Nutrient Contents in Different Manures}

The distribution characteristics of TN, TP and TK contents in swine, layer and dairy manures can be as- sessed from the histogram of analyzed samples (Figure 2).

The results of one-sample Kolmogorov-Smirnov test showed that the measured TN contents in swine and dairy manure samples followed normal distribution $(\mathrm{p}=$ $0.573, p=0.923)$. The TN contents of more than $2 / 3$ swine and dairy manure samples were in the ranges of 27 - $37 \mathrm{~g} \cdot \mathrm{kg}^{-1} \mathrm{DM}$ and $14-22 \mathrm{~g} \cdot \mathrm{kg}^{-1} \mathrm{DM}$ respectively. The frequency of TN contents in layer manures was positively skewed (Figure 2). There were 4 samples with very high TN contents of more than $125 \mathrm{~g} \cdot \mathrm{kg}^{-1} \mathrm{DM}$. The layer manure samples were collected from three different growth periods, including 4 samples from brooding stage, 8 from growing period and 79 from laying period. The 4 samples with high TN contents came from the brooding stage. It appears that the high crude protein contents in the feed and high remnant feed in manures contributed to
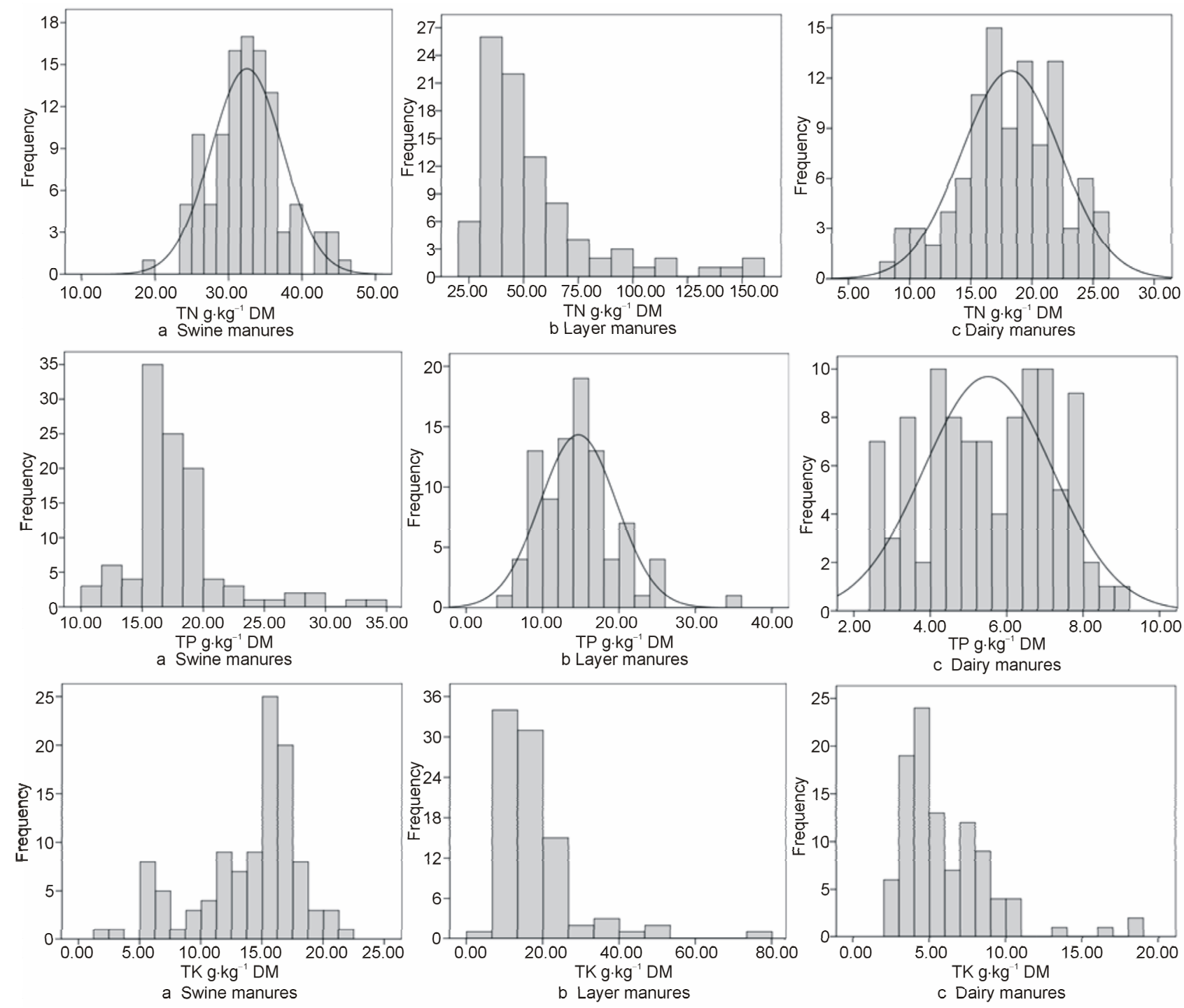

Figure 2. The frequency distribution of TN, TP and TK contents in swine, layer and dairy manures. 
the high TN contents in the 4 manure samples. The high variation of $\mathrm{TN}$ in layer manures was affected by these 4 samples. The histogram showed that the TN contents of layer manure samples were in the range of $30-60 \mathrm{~g} \cdot \mathrm{kg}^{-1}$ DM mainly.

The distribution of TP content for layer and dairy manure samples also followed normal distribution $(\mathrm{p}=$ $0.346, p=0.257$ ). More than $2 / 3$ samples of layer and dairy manures tested TP contents in the ranges of $9-20$ $\mathrm{g} \cdot \mathrm{kg}^{-1} \mathrm{DM}$ and $4-7 \mathrm{~g} \cdot \mathrm{kg}^{-1} \mathrm{DM}$. The TP contents in swine manure distributed centrally and about $75 \%$ swine manures samples were between $15 \mathrm{~g} \cdot \mathrm{kg}^{-1} \mathrm{DM}$ and 20 $\mathrm{g} \cdot \mathrm{kg}^{-1} \mathrm{DM}$ with the lowest $\mathrm{CV}$ value.

The frequency distribution of TK contents in layer and dairy manures is positively skewed (Figure 2). The mean value of TK content in layer and dairy manures were affected by samples with high TK content. Both CV values were higher than $50 \%$. The histogram showed that the TK contents of layer and dairy manure samples were in the ranges of $11-25 \mathrm{~g} \cdot \mathrm{kg}^{-1} \mathrm{DM}$ and $3-9 \mathrm{~g} \cdot \mathrm{kg}^{-1} \mathrm{DM}$ mainly. The TK content of swine manure samples was in the range of $11-19 \mathrm{~g} \cdot \mathrm{kg}^{-1} \mathrm{DM}$ mainly.

\section{CONCLUSION}

Nutrient content in livestock manures samples collected by floor scrapings in animal stables in Beijing suburbs was analyzed. All three types of manures showed a high variability in nutrient contents. Nutrients contents in different animal manures were significantly different according to the results of post hoc multiple comparisons test. Layer and swine manures had higher total nutrient values than dairy manures. Layer manures were rich in potassium and swine manures were rich in phosphorus. The result will provide a data base for environmental protection and safe utilization of livestock manures in Beijing area.

\section{ACKNOWLEDGEMENTS}

This work was supported by Special Fund for Agro-scientific Research in the Public Interest of China (No. 201003063) and by Program for New Century Excellent Talents in University (NCET-10-0785) and Chinese Universities Scientific Fund (2013RC019).

\section{REFERENCES}

[1] Pain, B.F. (2000) Control and utilization of livestock manures. In: Hopkins, A., Ed., Grass: Its Production and Utilization, 3rd Edition, British Grassland Society, Blackwell Science Ltd., Oxford, 343-364.

[2] MAFF, Ministry of Agriculture, Fisheries and Food (2010) Fertiliser recommendations for agricultural crops. 8th Edition, HMSO, London, Reference Book 209, 55-84.

[3] Nahm, K.H. (2007) Feed formulations to reduce N excre- tion and ammonia emission from poultry manure. Bioresource Technology, 98, 2282-2300.

http://dx.doi.org/10.1016/j.biortech.2006.07.039

[4] Leek, A.B.G., Hayes, E.T., Curran, T.P., Callan, J.J., Beattie, V.E., Dodd, V.A. and O'Doherty, J.V. (2007) The influence of manure composition on emissions of odor and ammonia from finishing pigs fed different concentrations of dietary crude protein. Bioresource Technology, 98, 3431-3439.

http://dx.doi.org/10.1016/j.biortech.2006.11.003

[5] Du, C.W., Zhou, G.Q., Zhou, J.M., Wang, H.Y., Chen, X.Q., Dong, Y.H. and Wang, H. (2010) Characterization of animal manures using mid-infrared photoacoustic spectroscopy. Bioresource Technology, 101, 6273-6277. http://dx.doi.org/10.1016/j.biortech.2010.03.010

[6] James, B. and Reeves III, J. (2001) Near-infrared diffuse Reflectance spectroscopy for the analysis of poultry manures. Journal of Agricultural and Food Chemistry, 49, 2193-2197. http://dx.doi.org/10.1021/jf0013961

[7] Li, S.T., Liu, R.L. and Shan, H. (2009) Nutrient contents in main animal manures in China. Journal of Agro-Environment Science, 28, 179-184.

[8] Lupwayi, N.Z., Girma, M. and Haque, I. (2000) Plant nutrient contents of cattle manures from small-scale farms and experimental stations in the Ethiopian highlands. Agriculture, Ecosystems \& Environment, 8, 57-63. http://dx.doi.org/10.1016/S0167-8809(99)00113-9

[9] Manfred Sager (2007) Trace and nutrient elements in manure, dung and compost samples in Austria. Soil Biology and Biochemistry, 39, 1383-1390. http://dx.doi.org/10.1016/j.soilbio.2006.12.015

[10] Overcash, M.R., Humenik, F.J. and Miner, J.R. (1983) Livestock waste management, Volume 1. CRC Press, Boca Raton.

[11] Reeves III, J.B. and Van Kessel, J.S. (2000) Near-infrared spectroscopic determination of carbon, total nitrogen and ammonium-N in dairy manure. Journal of Dairy Science, 83, 1829-1836. http://dx.doi.org/10.3168/jds.S0022-0302(00)75053-3

[12] Rico, J.L., García, H., Rico C. and Tejero I. (2007) Characterisation of solid and liquid fraction of dairy manure with regard to their component distribution and methane production. Bioresource Technology, 98, 971-979. http://dx.doi.org/10.1016/j.biortech.2006.04.032

[13] Teira-Esmatges, M.R. and Flotats, X. (2003) A method for livestock waste management planning in NE Spain. Waste Management, 23, 917-932.

[14] Xing, W.Y. and Li, R. (1999) Database of nutrients in organic manure in China. China Science and Technology Press, Beijing.

[15] Yang, Z.L., Han, L.J. and Fan X. (2006a) Rapidly estimating nutrient contents of fattening pig manure from floor scrapings by near infrared reflectance spectroscopy. Journal of Near Infrared Spectroscopy, 14, 261-268. http://dx.doi.org/10.1255/jnirs.643

[16] Yang, Z.L., Han, L.J., Li Q.F. and Piao X.S. (2006b) Estimating nutrient contents of pig slurries rapidly by measurement of physical and chemical properties. Journal of 
Agricultural Science, 144, 261-267. http://dx.doi.org/10.1017/S0021859606006095

[17] Kim, M.C., Song, S.T. and Hwang, K.J. (2004) Evaluation of slurry, urine and fermented liquid manure at pig farms in the Jeju area regarding chemical composition and pollution level. Journal of Animal Science and Technology, 46, 469-478.

http://dx.doi.org/10.5187/JAST.2004.46.3.469

[18] Millmier, A. Lorimor, J., Hurburgh, C., Fulhage, C., Hattey, J. and Zhang, H. (2000) Near-infrared sensing of manure nutrients. Transactions of ASAE, 43, 903-908. http://dx.doi.org/10.13031/2013.2986

[19] Jeffery, L., Charles, H., Tom, R., Jeffery, H., Charles, F. and Zhang, H.L. (2003) Near infrared technology to determine manure nutrients. Six States Consortium on Animal Wastes, Missouri. http://cafnr.missouri.edu/research/reports/i14.php

[20] Wang, K.J. (2004) Technology and policy of poultry and animal aqua-culture pollution prevention. Chemical Industry Press, Beijing.

[21] Shi, G.H. (2004) The impact of intensive livestock pro- duction on eco-environment and development countermeasure in Beijing suburban area. China Agricultural University, Beijing.

[22] Clesceri, L.S., Greenberg, A.E. and Eaton, A.D. (1998) Standard methods for the examination of water and wastewater. 20th Edition, American Public Health Association, Washington DC.

[23] USEPA (1986) Method 3051. Microwave assisted acid digestion of sediments, sludges and soils. In: Test Methods for Evaluating Solid Waste. Volume 1A, 3rd Edition, National Technical Information Service, Springfield.

[24] Norusis, M. (2008) SPSS 16.0 guide to data analysis. 2nd Edition, Prentice Hall, Inc., Upper Saddle-River.

[25] Wang, F.H., Ma, W.Q., Dou, Z.X., Ma, L., Liu, X.L., Xu, J.X. and Zhang, F.S. (2006) The estimation of the production amount of animal manure and its environment effect in China. China Environmental Science, 26, 614-617.

[26] National Bureau of Statistics of China (Beijing) (2010) Beijing statistical yearbook. China Statistics Press, Beijing. 